\title{
Effects of Cardamonin Enriched Diets on Growth, Intestinal Histology, Hematology, and Biochemical Parameters of Hybrid Catfish (Clarias macrocephalus $\times$ Clarias gariepinus)
}

\author{
Janeeya Khunchalee $^{1}$ and Phukphon Munglue ${ }^{2 *}$ \\ ${ }^{1}$ Program of Chemistry, Faculty of Science, Ubon Ratchathani Rajabhat \\ University, Ubon Ratchathani 34000, Thailand \\ ${ }^{2}$ Program of Biology, Faculty of Science, Ubon Ratchathani Rajabhat University, \\ Ubon Ratchathani 34000, Thailand \\ *Corresponding author.Email:phukphon.m@ubru.ac.th,d5010172@g.sut.ac.th \\ https://doi.org/10.12982/CMUJNS.2020.0056 \\ Received: December 14, 2019 \\ Revised: March 3, 2020 \\ Accepted: March 12, 2020
}

\begin{abstract}
This research was aimed to evaluate the effects of cardamonin enriched diets on growth, intestinal histology, hematology, and biochemical parameters of hybrid catfish (Clarias macrocephalus $\times$ Clarias gariepinus). Fish (the initial weight of $7.00 \pm 1.00 \mathrm{~g}$ ) were fed with the diets containing cardamonin at 0 (control), 5 , and $10 \mathrm{mg} / \mathrm{kg}$ diet for 8 weeks. After the feeding period, it was found that cardamonin enriched diets significantly enhanced growth parameters and feed utilization efficiency compared with the control $(P<0.05)$. Additionally, cardamonin enriched diets significantly increased villi height, villi width, absorptive area, muscle thickness, and goblet cell compared with the control diets $(P<0.05)$. Hematological indices including hemoglobin, hematocrit, white blood cell, red blood cell, mean corpuscular volume, mean corpuscular hemoglobin, and mean corpuscular hemoglobin concentration did not differ among the treatments (P>0.05). Serum cholesterol, high-density lipoprotein, low-density lipoprotein, aspartate aminotransferase, alkaline phosphatase, and creatinine were unaffected by cardamonin enriched diets (P>0.05), meanwhile, albumin levels of the tested fish were significantly increased compared with the control $(P<0.05)$. In conclusion, these findings indicate that cardamonin could be used as a phytogenic feed additive to enhance the growth of hybrid catfish and the effective level observed was 10 $\mathrm{mg} / \mathrm{kg}$ diet.
\end{abstract}

Keywords: Cardamonin, Hybrid catfish, Growth, Physiological responses, Phytogenics 


\section{INTRODUCTION}

Catfish are important farmed fish species that have been generally cultured around the globe due to their high growth rate and nutritional value. In Thailand, total annual catfish production was approximately $102,443.77$ metric tons worth 4,843.57 million baht in 2016 (Fishery Statistics Analysis and Research Group, 2019). In recent years, intensive and semi-intensive culture systems of fish have been conducted to meet the growing demands for fish consumption. However, high rearing densities may cause negative effects on the health status of fish (Awad and Awaad, 2017; Hoseini et al., 2018). The application of antibiotics or synthetic compounds to the fish diets could produce drug-resistant pathogens, drug residues in meat, immunosuppression, and environmental hazards (Reda et al., 2013; Lim et al., 2019). In this phenomenon, several researchers are now searching for novel compounds to substitute the use of chemicals in aquaculture industries such as prebiotics, probiotics, and phytogenics (Aanyu et al., 2018; Cao et al., 2019; Munglue et al., 2019a; Li et al., 2019).

Plants are served as important sources for drug discovery both in pharmaceutical and aquaculture industries (Reverter et al., 2014; Van Hai, 2015). Interestingly, medicinal plant extracts and their isolated phytochemicals have been tested for their antioxidant, anti-inflammatory, antiviral, and antibacterial characteristics (Awad and Awaad, 2017). It has been reported that the applications of such plant extracts as phytogenic feed additives to the diets produced the improvement in growth performance, nutrient metabolism, and immune systems in farmed fish (Reverter et al., 2014). The previous study indicated that juvenile golden pompano (Trachinotus ovatus) fed the diets supplemented with dandelion extract for 8 weeks significantly exerted beneficial effects on growth, intestinal histology, antioxidant activity, and immune responses (Tan et al., 2018). Similarly, Güllü et al. (2015) exhibited that tilapia (Oreochromis mossambicus) received the inclusion of allspice (Pimenta dioica) powder improved hematological and serum biochemical indices as well as immunological parameters in tilapia after 60 days of feeding.

Cardamonin ( $\left(2,4^{\prime}\right.$-dihydroxy-6'-methoxychalcone) is a flavonoid that was firstly isolated from the seeds of Alpinia speciosa (Krishna and Chaganty, 1973). Recently, this compound has been isolated from different plant species like Alpinia blepharocalyx (Dong et al., 1998), Alpinia gagnepainii (Tram et al., 2007), Syzygium campanulatum Korth (Menon et al., 2014), and Boesenbergia rotunda (Kiat et al., 2006; Isa et al., 2013). It was proposed that cardamonin proved to have anti-inflammatory (Hatziieremia et al., 2006), anticancer (Memon et al., 2014; Zhang et al., 2017), antioxidant (Bajgai et al., 2011), antiviral (Tewtrakul et al., 2003), vasorelaxant (Wang et al., 2001), antinociceptive (Ping et al., 2018), and hypoglycemic activities (Yamamoto et al., 2011). There is evidence that the diets supplemented with Thai ginseng (B. rotunda), a rich 
source of cardamonin, produced significant increases in somatic growth, immune responses, and disease resistance against Streptococcus agalactiae in Nile tilapia (Oreochromis niloticus) (Van Doan et al., 2019). These findings led to support the potential use of $B$. rotunda and cadamomin as phytogenics in aquaculture production (Van Doan et al., 2019). Nowadays, there are no publications of the use of cardamonin as a growth-promoting agent in the culture of fish.

As there is an urgent need to find effective phytogenic compounds for the improvement in the growth and health status in aquatic animals, and novel compounds are recently reported (Aanyu et al., 2018; Sruthi et al., 2018), the aim of this research was conducted to evaluate the effects of diets containing cardamonin, a flavonoid isolated from $B$. rotunda extract, on growth performance, intestinal histology, hematology, and blood biochemistry of hybrid catfish (Clarias macrocephalus $\times$ Clarias gariepinus).

\section{MATERIALS AND METHODS}

\section{Plant preparation and extraction}

The samples of $B$. rotunda rhizomes were obtained from the local market and authenticated. A voucher specimen (Munglue 005) was deposited at the Program of Biology, Faculty of Science, Ubon Ratchathani Rajabhat University for further reference. Fresh rhizomes were cleaned using distilled water, cut into small pieces, macerated with ethanol $(1: 2 \mathrm{w} / \mathrm{v})$ for 7 days. The extraction procedures were done in triplicate. The extracts were filtrated, removed the solvent by rotary evaporator under reduced pressure and low temperature, and dried by lyophilizer. The plant extract was chromatographed over silica gel. The characterization of cardamonin was achieved by using IR and ${ }^{1} \mathrm{H}$ and ${ }^{13} \mathrm{C}-\mathrm{Nuclear}$ Magnetic Resonance (NMR) as previously reported by Memon et al. (2014).

Cardamonin was recrystallized using a mixture of methanol-n-hexane (1:9) and was obtained as yellow needle crystals, having m.p. $192-193^{\circ} \mathrm{C}$. FTIR spectrum showed a strong and sharp vibration band at $3,401 \mathrm{~cm}^{-1}$ that exhibited the presence of $(-\mathrm{OH})$ group, 2,932 $\mathrm{cm}^{-1}\left(\mathrm{CH}_{3}\right), 1,677 \mathrm{~cm}^{-1}(\mathrm{C}=\mathrm{O})$, and $1,541 \mathrm{~cm}^{-1}(\mathrm{CH}=\mathrm{CH})$. The ${ }^{1} \mathrm{H}$ NMR spectrum of this compound in $\mathrm{CDCl}_{3}$; showed a singlet peak at $\delta 3.34\left(3 \mathrm{H}, \mathrm{s}, 2^{\prime}-\mathrm{OCH}_{3}\right)$. Meta coupling related two doublets at $\delta 5.96(1 \mathrm{H}, \mathrm{d}, \mathrm{J}=1.8 \mathrm{~Hz})$ and $\delta 6.03(1 \mathrm{H}, \mathrm{d}, \mathrm{J}=2.1 \mathrm{~Hz})$. Another two sets of doublets at $\delta 7.60(1 \mathrm{H}, \mathrm{d}, \mathrm{J}=16.4 \mathrm{~Hz}, \mathrm{H}-7)$ and $\delta 7.84(1 \mathrm{H}, \mathrm{d}, \mathrm{J}=14.1 \mathrm{~Hz}$, $\mathrm{H}-8$ ) represented a trans olefin group. A multiplet was found to be between $\delta 7.40$ and $7.42\left(5 \mathrm{H}\right.$, multiplet). The ${ }^{13} \mathrm{C}$ NMR spectrum showed a singlet peak at $\delta 130.06,128.88,128.35,127.54,96.76$, and 91.05. However, it has two olefinic carbon atoms at $\delta 128.30$ and 142.42 , respectively. The chemical structure of cardamonin is shown in Figure 1. 


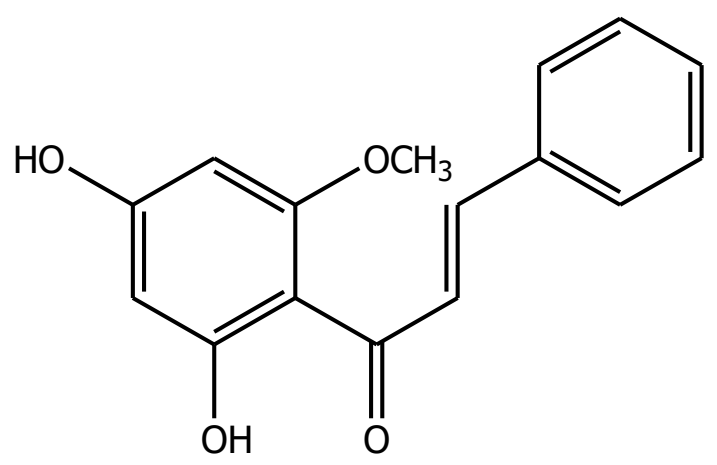

Figure 1. The chemical structure of cardamonin.

\section{Diet preparations}

The experimental diet (Centaco No. 3134) containing 32\% protein, 4\% lipid, $45 \%$ carbohydrate, $6 \%$ fiber, and $12 \%$ moisture for catfish fingerlings was purchased from a local feed company (Centaco Group of Companies, Thailand). The diets were mixed with cardamonin at the levels of 0 (control), 5, and 10 $\mathrm{mg} / \mathrm{kg}$ diet by using cassava starch as a binder. All doses of cardamonin used in this study were determined by referring to the reports of Rodriguez Montes de Oca (2005) and Aanyu et al. (2018). The diet samples were dissolved with distilled water $(100 \mathrm{ml} / \mathrm{kg}$ diet $)$, mixed with a meat mincer, dried in a hot air oven at $45^{\circ} \mathrm{C}$ for $72 \mathrm{~h}$, and kept in label zip-lock bags at $4^{\circ} \mathrm{C}$ until used.

\section{Fish preparations}

Hybrid catfish fingerlings were obtained from Ubon Ratchathani Fishery Cooperative, Ubon Ratchathani, Thailand. The fish were maintained in a circular concrete tank ( $40 \mathrm{~cm}$ height and $80 \mathrm{~cm}$ width) containing dechlorinated water 300 $\mathrm{L}$, acclimatized under the laboratory conditions for 2 weeks, and fed with the basal diet. After the acclimatization period, fish (the initial weight of $7.00 \pm 1.00$ $\mathrm{g}$ ) were then randomly distributed into 3 treatments and each treatment consisted of 3 replications (20 fish per replication). Fish were fed with the experimental diets twice a day, ad libitum, for 8 weeks. Water qualities were kept at the standard conditions for the culture of hybrid catfish (Abdel-Tawwab et al., 2018). The water was partially changed (approximately 50\%) every day. Fish health status and well-being were observed daily during the acclimatization and experimental periods. The experimental procedures were attained as the guideline for the care and use of laboratory animals provided by the National Research Council of Thailand and Ubon Ratchathani Rajabhat University, Thailand.

\section{Growth parameters and survival rate}

At the end of the experimental period, fish were fasted for $24 \mathrm{~h}$, randomly collected, and anaesthetized with clove oil ( $5 \mathrm{ppm})$ to evaluate growth rates using the following formulae (Munglue et al., 2019a): 
Weight gain (WG; g) = final weight $(\mathrm{g})$ - initial weight $(\mathrm{g})$;

Specific growth rate $(\mathrm{SGR} ; \% /$ day $)=100 \times[(I n$ final weight $(\mathrm{g})-\operatorname{In}$ initial weight $(\mathrm{g})) /$ the experimental period (days)];

Average daily gain $(\mathrm{ADG} ; \mathrm{g} /$ day $)=$ weight gain $(\mathrm{g}) /$ the experimental period (days);

Feed conversion ratio $(\mathrm{FCR})=$ dry feed fed $(\mathrm{g}) /$ weight gain $(\mathrm{g})$;

Condition factor $\left(\mathrm{CF} ; \mathrm{g} / \mathrm{cm}^{3}\right)=$ final weight $(\mathrm{g}) /$ final length $(\mathrm{cm})^{3}$;

Survival rate $(\mathrm{SR} ; \%)=100 \times($ final number of fish/initial number of fish $)$.

\section{Blood sample and analysis}

Four fasted fish from each tank were anaesthetized to collect the blood sample from the caudal vein using the syringe containing Ethylenediamine tetraacetic acid (EDTA) as an anticoagulant agent. The blood sample was divided into 2 parts.

One part was transferred into Eppendorf tubes to evaluate hematological parameters including hemoglobin $(\mathrm{Hb})$, hematocrit $(\mathrm{Hct})$, white blood cell (WBC), red blood cell (RBC), mean corpuscular volume (MCV), mean corpuscular hemoglobin $(\mathrm{MCH})$, and mean corpuscular hemoglobin concentration (MCHC) as previously reported by Briggs and Bain (2017).

The second part was transferred into Eppendorf tubes and left to clot at room temperature, centrifuged at $5,000 \mathrm{rpm}, 4^{\circ} \mathrm{C}$ for $15 \mathrm{~min}$ in order to collect the serum. Fish sera were kept at $-20^{\circ} \mathrm{C}$ for further blood biochemical analysis. Blood biochemical parameters including cholesterol, high-density lipoprotein (HDL), low-density lipoprotein (LDL), aspartate aminotransferase (AST), alkaline phosphatase (ALP), albumin, and creatinine were measured using the commercial kits obtained from Erba Lachema s.r.o., Czech Republic.

\section{Intestinal histology}

Four fish from each tank were anaesthetized and the abdominal cavity opened. The intestine was carefully removed and divided into three portions: proximal, middle, and distal intestine. The intestinal segment (approximately $1 \mathrm{~cm}$ ) of each portion was cut, cleared any intestinal contents, and fixed in $10 \%$ neutral phosphate-buffered formalin. The collected intestinal sample was dehydrated in graded ethanol, equilibrated in xylene, and embedded in paraffin wax. The sample was cut (approximately $5 \mu \mathrm{m}$ ) and stained with haematoxylin and eosin (H \& E).

To assess the effects of dietary cardamonin on the histological structure of the intestines, the height of villi, width of the villi, thickness of the muscle layers, and the number of goblet cells were observed under a light microscope connected to Dino-Eye eyepiece camera (AnMo Electronics Corporation, Taiwan). 
The images from the camera were recorded on a computer using DinoCapture 2.0 software. The absorptive area of the intestine was quantified using the following equation (Abdel-Tawwab et al., 2018).

Absorptive area $\left(\mu \mathrm{m}^{2}\right)=$ villi height $(\mu \mathrm{m}) \times$ villi width $(\mu \mathrm{m})$

\section{Statistical analysis}

The normality of data and homogeneity of variances were analyzed by using Kolmogorov-Smirnov test and Levene test, respectively (Picoli et al., 2019). All data presented in this study are expressed as Mean \pm SEM. Data were analyzed by one-way analysis of variance (ANOVA). To evaluate significant differences between treatments at a significant level of 95\%, Duncan's multiplerange test was used.

\section{RESULTS}

\section{Growth parameters and survival rate}

As shown in Table 1, fish that were fed with cardamonin enriched diets showed significant increases in the final weight, final length, WG, SGR, and ADG compared with the control $(P<0.05)$. Meanwhile, significant decreases in the FCR levels of the tested fish were observed compared with the control $(P<0.05)$. The condition factor and survival rate did not differ among the treatments $(P>0.05)$.

Table 1. Growth and survival of hybrid catfish fed cardamonin enriched diets for 8 weeks.

\begin{tabular}{lccc}
\hline & \multicolumn{3}{c}{ Cardamonin (mg/kg diet) } \\
\cline { 2 - 4 } & $\mathbf{0}$ & $\mathbf{5}$ & $\mathbf{1 0}$ \\
\hline IW (g) & $7.58 \pm 0.14$ & $7.41 \pm 0.27$ & $7.50 \pm 0.28$ \\
FW (g) & $45.91 \pm 1.41^{\mathrm{c}}$ & $54.75 \pm 1.37^{\mathrm{b}}$ & $60.91 \pm 2.36^{\mathrm{a}}$ \\
IL (cm) & $10.62 \pm 0.19$ & $10.45 \pm 0.15$ & $10.37 \pm 0.16$ \\
FL (cm) & $16.83 \pm 0.24^{\mathrm{b}}$ & $18.50 \pm 0.28^{\mathrm{a}}$ & $18.16 \pm 0.23^{\mathrm{a}}$ \\
WG (g) & $38.33 \pm 1.37^{\mathrm{c}}$ & $47.33 \pm 1.46^{\mathrm{b}}$ & $53.41 \pm 2.36^{\mathrm{a}}$ \\
SGR (\%/day) & $3.21 \pm 0.05^{\mathrm{c}}$ & $3.57 \pm 0.09^{\mathrm{b}}$ & $3.74 \pm 0.08^{\mathrm{a}}$ \\
ADG (g/day) & $0.68 \pm 0.02^{\mathrm{c}}$ & $0.84 \pm 0.01^{\mathrm{b}}$ & $0.95 \pm 0.04^{\mathrm{a}}$ \\
FCR & $2.81 \pm 0.09^{\mathrm{b}}$ & $2.26 \pm 0.06^{\mathrm{a}}$ & $2.02 \pm 0.08^{\mathrm{a}}$ \\
CF (g/cm $\left.{ }^{3}\right)$ & $0.98 \pm 0.06$ & $0.87 \pm 0.03$ & $1.03 \pm 0.05$ \\
SR (\%) & $100 \pm 1.00$ & $99.16 \pm 0.83$ & $99.16 \pm 0.83$ \\
\hline
\end{tabular}

Note: Data are expressed as mean \pm SEM. Different superscripts ${ }^{(a-c)}$ in the same line indicate a significant difference between the control and cardamonin-treated groups $(P<0.05)$. IW $=$ initial weight $(\mathrm{g}) ; \mathrm{FW}=$ final weight $(\mathrm{g}) ; \mathrm{IL}=$ initial length $(\mathrm{cm}) ; \mathrm{FL}=$ final length $(\mathrm{cm}) ; \mathrm{WG}=$ weight gain $(\mathrm{g})$; SGR = specific growth rate $(\% /$ day $) ; \mathrm{ADG}=$ average daily gain $(\mathrm{g} / \mathrm{day}) ; \mathrm{FCR}=$ feed conversion ratio $\mathrm{CF}=$ condition factor $\left(\mathrm{g} / \mathrm{cm}^{3}\right) ; \mathrm{SR}=$ survival rate $(\%)$. 


\section{Intestinal histology}

The effects of cardamonin enriched diets on the intestinal histology of hybrid catfish are shown in Figure 2 and the mean data presented in Table 2.

In the proximal intestine, fish that were fed with the diets containing cardamonin showed significant increases in villi height, villi width, absorptive area, inner circular smooth muscle, and goblet cell compared with the control $(P<0.05)$. In contrast, the outer longitudinal smooth muscle was significantly decreased in the tested fish compared with the control fish $(P<0.05)$.

In the middle intestine, significant increases in villi height, villi width, absorptive area, inner circular smooth muscle, outer longitudinal smooth muscle, and goblet cell were detected in the experimental treatments compared with the control $(P<0.05)$.

In the distal intestine, villi height, villi width, absorptive area, inner circular smooth muscle, outer longitudinal smooth muscle, and goblet cell were significantly increased in fish that were fed with cardamonin enriched diets compared with the control $(P<0.05)$.
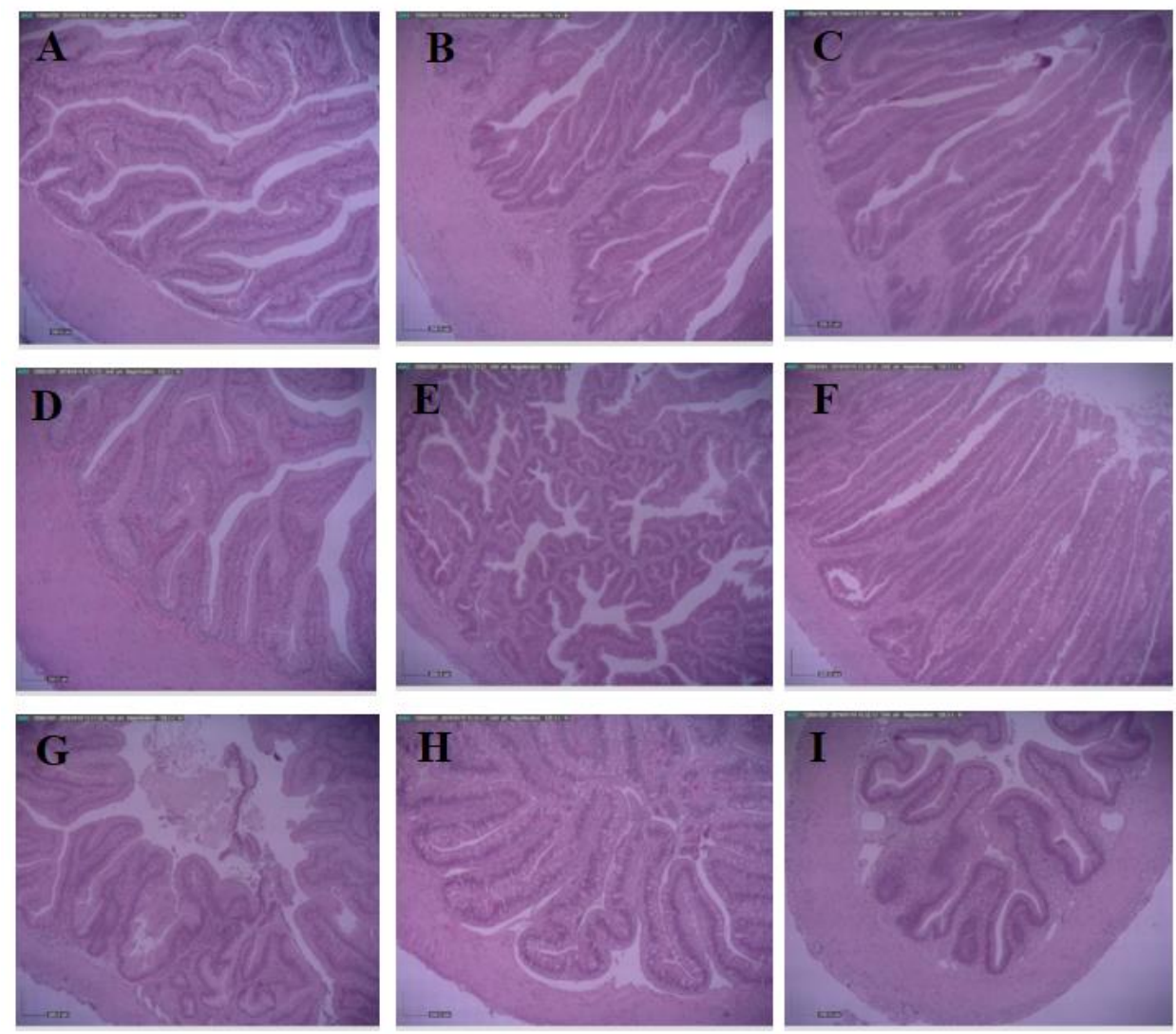

Figure 2. Proximal (A-C), middle (D-F), and distal (G-I) parts of the intestines of hybrid catfish that were fed with the diets containing cardamonin at 0 (control) (A, D, and G), 5 (B, E, and H), and 10 (C, F, and I) $\mathrm{mg} / \mathrm{kg}$ diet for 8 weeks (Scale bar $=200 \mu \mathrm{m})$. 
Table 2. Intestinal histology of hybrid catfish fed cardamonin enriched diets for 8 weeks.

\begin{tabular}{lccc}
\hline & \multicolumn{3}{c}{ Cardamonin (mg/kg diet) } \\
\cline { 2 - 4 } & $\mathbf{0}$ & $\mathbf{5}$ & $\mathbf{1 0}$ \\
\hline Proximal intestine & $1073.82 \pm 100.96^{\mathrm{b}}$ & $1930.05 \pm 58.12^{\mathrm{a}}$ & $2012.88 \pm 56.97^{\mathrm{a}}$ \\
Villi height (um) & $91.52 \pm 1.72^{\mathrm{b}}$ & $101.51 \pm 7.19^{\mathrm{b}}$ & $134.63 \pm 4.36^{\mathrm{a}}$ \\
Villi width (um) & $101360.62 \pm 8816.18^{\mathrm{b}}$ & $196702.37 \pm 19787.58^{\mathrm{a}}$ & $256807.58 \pm 21820.43^{\mathrm{a}}$ \\
Absorptive area (um ${ }^{2}$ ) & $167.26 \pm 18.67^{\mathrm{b}}$ & $222.93 \pm 28.66^{\mathrm{a}}$ & $290.84 \pm 20.03^{\mathrm{a}}$ \\
Inner circular muscle (um) & $152.17 \pm 82.93$ & $107.67 \pm 8.26$ & $110.59 \pm 10.99$ \\
Outer longitudinal muscle (um) & $22.50 \pm 2.18^{\mathrm{b}}$ & $30.25 \pm 3.10^{\mathrm{a}}$ & $27.50 \pm 1.81^{\mathrm{a}}$ \\
Goblet cell & & & \\
\hline Middle intestine & $1124.04 \pm 114.48^{\mathrm{b}}$ & $1323.72 \pm 61.81^{\mathrm{ab}}$ & $1528.28 \pm 84.72^{\mathrm{a}}$ \\
Villi height (um) & $110.62 \pm 2.76^{\mathrm{b}}$ & $141.09 \pm 5.93^{\mathrm{a}}$ & $143.04 \pm 4.25^{\mathrm{a}}$ \\
Villi width (um) & $123714.87 \pm 9348.70^{\mathrm{b}}$ & $186611.35 \pm 10626.65^{\mathrm{a}}$ & $217983.93 \pm 7357.08^{\mathrm{a}}$ \\
Absorptive area (um ${ }^{2}$ ) & $153.52 \pm 12.31^{\mathrm{b}}$ & $195.09 \pm 10.93^{\mathrm{a}}$ & $199.81 \pm 11.74^{\mathrm{a}}$ \\
Inner circular muscle (um) & $57.07 \pm 3.73^{\mathrm{c}}$ & $94.46 \pm 6.01^{\mathrm{b}}$ & $128.10 \pm 6.40^{\mathrm{a}}$ \\
Outer longitudinal muscle (um) & $23.59 \pm 1.78^{\mathrm{b}}$ & $22.11 \pm 1.70^{\mathrm{b}}$ & $28.75 \pm 1.78^{\mathrm{a}}$ \\
Goblet cell & & & \\
\hline Distal intestine & $1344.60 \pm 39.87^{\mathrm{c}}$ & $1739.89 \pm 50.81^{\mathrm{a}}$ & $1560.45 \pm 93.27^{\mathrm{b}}$ \\
Villi height (um) & $86.84 \pm 3.39^{\mathrm{c}}$ & $119.12 \pm 4.42^{\mathrm{b}}$ & $131.10 \pm 2.86^{\mathrm{a}}$ \\
Villi width (um) & $93611.76 \pm 5163.45^{\mathrm{b}}$ & $207424.60 \pm 11395.04^{\mathrm{a}}$ & $204313.38 \pm 10884.20^{\mathrm{a}}$ \\
Absorptive area (um ${ }^{2}$ ) & $160.20 \pm 10.42^{\mathrm{c}}$ & $331.55 \pm 52.48^{\mathrm{a}}$ & $232.04 \pm 22.80^{\mathrm{b}}$ \\
Inner circular muscle (um) & $70.74 \pm 7.01^{\mathrm{b}}$ & $127.24 \pm 4.16^{\mathrm{a}}$ & $139.11 \pm 10.96^{\mathrm{a}}$ \\
Outer longitudinal muscle (um) & $37.91 \pm 4.79^{\mathrm{b}}$ & $100.66 \pm 10.30^{\mathrm{a}}$ & $30.91 \pm 2.69^{\mathrm{b}}$ \\
Goblet cell & & & \\
\hline & & & \\
\hline
\end{tabular}

Note: Data are expressed as mean \pm SEM. Different superscripts ${ }^{(a-c)}$ in the same line indicate a significant difference between the control and cardamonin-treated groups $(P<0.05)$. 


\section{Hematological indices}

As indicated in Table 3, the levels of $\mathrm{Hb}, \mathrm{Hct}$, WBC, RBC, MCV, MCH, and $\mathrm{MCHC}$ of fish that were fed with the diets supplemented with cardamonin did not change significantly compared with the control $(P>0.05)$.

Table 3. Hematology of hybrid catfish fed cardamonin enriched diets for 8 weeks.

\begin{tabular}{lrrr}
\hline & \multicolumn{3}{c}{ Cardamonin (mg/kg diet) } \\
\cline { 2 - 4 } & \multicolumn{1}{c}{$\mathbf{0}$} & \multicolumn{1}{c}{$\mathbf{5}$} & \multicolumn{1}{c}{$\mathbf{1 0}$} \\
\hline $\mathrm{Hb}(\mathrm{mg} / \mathrm{dl})$ & $13.18 \pm 0.51$ & $12.60 \pm 0.37$ & $11.20 \pm 0.49$ \\
$\mathrm{Hct}(\%)$ & $36.60 \pm 2.17$ & $35.71 \pm 0.50$ & $33.25 \pm 0.56$ \\
$\mathrm{WBC}\left(\times 10^{4} \mathrm{cell} / \mathrm{mm}^{3}\right)$ & $5.39 \pm 1.15$ & $4.13 \pm 2.82$ & $4.37 \pm 1.25$ \\
$\mathrm{RBC}\left(\times 10^{12} \mathrm{cell} / \mathrm{l}\right)$ & $2.99 \pm 0.12$ & $2.93 \pm 0.04$ & $2.33 \pm 0.12$ \\
MCV $(\mathrm{fl})$ & $1.25 \pm 3.62$ & $1.23 \pm 0.45$ & $1.26 \pm 1.22$ \\
MCH (pg) & $45.25 \pm 0.82$ & $45.40 \pm 0.54$ & $46.30 \pm 0.78$ \\
MCHC $(\mathrm{g} / \mathrm{dl})$ & $36.18 \pm 1.13$ & $36.80 \pm 0.44$ & $36.70 \pm 0.43$ \\
\hline
\end{tabular}

Note: Data are expressed as mean \pm SEM. Mean presented indicated no significant difference between the control and cardamonin-treated groups $(P>0.05) . \mathrm{Hb}=$ hemoglobin $(\mathrm{mg} / \mathrm{dl}) ; \mathrm{Hct}=$ hematocrit $(\%)$; WBC = white blood cell $\left(\times 10^{4}\right.$ cell $\left./ \mathrm{mm}^{3}\right) ; \mathrm{RBC}=$ red blood cell $\left(\times 10^{12}\right.$ cell/l $) ; \mathrm{MCV}=$ mean corpuscular volume $(\mathrm{fl})$; $\mathrm{MCH}=$ mean corpuscular hemoglobin $(\mathrm{pg})$; and $\mathrm{MCHC}=$ mean corpuscular hemoglobin concentration $(\mathrm{g} / \mathrm{dl})$.

\section{Blood biochemistry indices}

As demonstrated in Table 4, fish that were fed with cardamonin containing diets did not show any change in serum cholesterol, HDL, LDL, AST, ALP, and creatinine compared with the control $(P>0.05)$. In contrast, serum albumin levels of the experimental fish were significantly higher than those of the control fish $(P<0.05)$.

Table 4. Blood biochemistry of hybrid catfish fed cardamonin enriched diets for 8 weeks.

\begin{tabular}{lccc}
\hline & \multicolumn{3}{c}{ Cardamonin (mg/kg diet) } \\
\cline { 2 - 4 } & $\mathbf{0}$ & $\mathbf{5}$ & $\mathbf{1 0}$ \\
\hline Cholesterol (mg/dl) & $334.88 \pm 25.71$ & $244.31 \pm 20.22$ & $202.11 \pm 26.81$ \\
HDL (mg/dl) & $2.07 \pm 0.17$ & $1.84 \pm 0.26$ & $1.38 \pm 0.25$ \\
LDL (mg/dl) & $0.23 \pm 0.05$ & $0.22 \pm 0.03$ & $0.18 \pm 0.03$ \\
AST (U/l) & $219.84 \pm 24.81$ & $239.38 \pm 17.61$ & $175.87 \pm 28.31$ \\
ALP (U/l) & $33.31 \pm 3.48$ & $35.56 \pm 2.24$ & $33.71 \pm 2.28$ \\
Albumin (mg/dl) & $0.77 \pm 0.12^{\mathrm{b}}$ & $1.21 \pm 0.08^{\mathrm{a}}$ & $1.30 \pm 0.07^{\mathrm{a}}$ \\
Creatinine (mg/dl) & $0.84 \pm 0.33$ & $0.72 \pm 0.26$ & $1.51 \pm 0.27$ \\
\hline
\end{tabular}

Note: Data are expressed as mean \pm SEM. Different superscripts $(a, b)$ in the same line indicate a significant difference between the control and cardamonin-treated groups $(P<0.05)$. HDL $=$ high-density lipoprotein $(\mathrm{mg} / \mathrm{dl})$; LDL = low-density lipoprotein $(\mathrm{mg} / \mathrm{dl})$; AST = aspartate aminotransferase (U/l); ALP $=$ alkaline phosphatase $(\mathrm{U} / \mathrm{l})$. 


\section{DISCUSSION}

This present study provides the first evidence that cardamom enriched diets improved growth, intestinal histology, and blood biochemistry. There were no changes in hematological parameters between the treatments. Therefore, these findings provide evidence supporting that cardamonin could be useful as a novel phytogenic in aquaculture industries.

In this study, significant increases in growth rate and feed utilization were detected in fish that were fed with cardamonin enriched diets. However, the survival rate did not differ significantly among the treatments. This result indicates that cardamonin did not produce any adverse effects in hybrid catfish. Recently, an attempt has been made to evaluate the effects of medicinal products and their isolated compounds on growth and immune status of aquatic animals (Reverter et al., 2014; Aanyu et al., 2018; Munglue et al., 2019b). In line with the present study, Li et al. (2019) indicated that dietary supplementation with flavonoids from Allium mongolicum Regel produced the improvement in the growth parameters of juvenile northern snakehead fish (Channa argus). The growth regulating effects of medicinal plants on fish are not well understood. However, many reports have indicated that herbs or their phytochemicals would predominantly up-regulate the expression of growth-related genes in fish such as growth and insulin-like growth factors (Aanyu et al., 2018; Sruthi et al., 2018; Ahmadifar et al., 2019). Also, there are reports by others that medicinal plants would increase appetite, feed consumption, and digestive enzyme secretion, which would contribute to the improvement of somatic growth and feed utilization efficiently (Van Hai, 2015; Ramezanzadeh et al., 2019; Van Doan et al., 2019).

Studies on intestinal histology could be used to assess nutritional physiology mechanisms of the growth-promoting properties of phytogenic feed additive in cultured fish (Fang et al., 2015; Tan et al., 2018). In this study, it was found that fish that were fed with cardamonin diets showed significant increases in villi height, villi height, absorptive area, muscular thicknesses, and goblet cell number compared with the control. It is well established that nutrient digestive and absorptive processes principally occur in the intestine of fish (Lazo et al., 2011). Therefore, increases in villi height and absorptive area could enhance the intestinal nutrition absorption area, which directly related to an increase in nutrient assimilation and growth of fish (Sun et al., 2018; Tan et al., 2018; Munglue et al., 2019a). Significant increases in muscular layers suggest the improvement in intestinal peristalsis which would modulate mucosal movement to mix the digested food with secretions and to propel unabsorbable contents anally (Lazo et al., 2011; Wilson and Castro, 2011). In this current study, increased intestinal muscular layers were observed in fish that were fed with cardamonin containing diets, which would contribute to the improvement in 
digestion and absorption of nutrients. Goblet cells are the secretory epithelial cells lining the surface of the mucous membrane of fish intestines. Previous studies have shown that goblet cells play a pivotal role in the protection and lubrication of intestinal lumen by producing mucous glycoproteins called mucins (Birchenough et al., 2015; Tiengtam et al., 2015). The results of this study showed a significant increase in the goblet cell number in cardamonin treatments compared with the control. It is possible that dietary supplementation with cardamonin would predominantly influence intestinal cell proliferation and differentiation, resulting in an increase in the goblet cell number as demonstrated by Villasante et al. (2016) and Tan et al. (2018).

Observations on hematological indices have been extensively used to evaluate the health status of fish. In the present research, there were no changes in $\mathrm{Hct}, \mathrm{Hb}, \mathrm{WBC}, \mathrm{RBC}, \mathrm{MCV}, \mathrm{MCH}$, and MCHC among the treatments. These findings suggested that cardamonin did not affect hematopoiesis in hybrid catfish. Likewise, hematological variables observed in this present research are within the reference intervals for hybrid catfish (Al-Dohail et al., 2009). In a similar study, Pês et al. (2016) indicated that silver catfish (Rhamdia quelen) that were fed with quercetin added diets did not show any change in $\mathrm{Hct}, \mathrm{Hb}$, and MCHC compared with the control. Additionally, dietary supplemented with rutin did not affect hematological values of silver catfish (Pês et al., 2015).

Blood biochemical values are generally used to notice the physiological responses of fish when the growth-enhancing effects of some dietary supplements are tested (Reda et al., 2013; Hoseini et al., 2018). Increased serum total protein, albumin, and globulin levels are directly associated with the improved immune function of fish (Güllü et al., 2015). The present study observed that the diets containing cardamonin significantly increased serum albumin levels. These results would indicate the modulation of nonspecific defense mechanisms or protein metabolism by cardamonin in fish (Güllü et al., 2015; Sarvi Moghanloa et al., 2018). Serum cholesterol, HDL, and LDL levels are commonly used as indicators of lipid metabolism and lipid peroxidation in fish (Mutlu et al., 2015; Lim et al., 2019). In the current study, there were no changes in cholesterol, HDL, and LDL of fish that were fed with the tested diets. It is indicated that cardamonin did not affect lipid metabolism in fish. Serum AST, ALP, and creatinine are commonly used for detecting and monitoring the health status of fish. Increased AST levels mostly indicate cellular damages occurred in the liver, heart, kidneys, and muscles (Adham et al., 2002; Marshall et al., 2012; Mutlu et al., 2015). Additionally, a high concentration of ALP could reveal any damages to the liver, bone, and RBC (Adham et al., 2002; Hoseini et al., 2018). Creatinine levels are related to gill and kidney functions as well as muscular tissue metabolism (Marshall et al., 2012; Reda et al., 2013; Mutlu et al., 2015). In this study, AST, ALP, and creatinine levels of fish fed the diets supplemented with cardamonin 
were similar to the control, suggesting that cardamonin did not affect the cellular integrity of the liver, heart, kidneys, gills, and muscles of fish.

\section{CONCLUSION}

This present study suggested that cardamonin could be useful as a phytogenic feed additive in the aquaculture industry because this natural substance showed a significant improvement in growth, intestinal histology, and blood biochemistry without negative effects. The optimal concentration of cardamonin in this current study was $10 \mathrm{mg} / \mathrm{kg}$ diet.

\section{ACKNOWLEDGEMENTS}

The authors would like to thank Miss Nutthaphon Phaphon and Miss Punprapa Pinnakilay for their help during the experimental period. The authors also acknowledge the Faculty of Science, Ubon Ratchathani Rajabhat University for the facilities support.

\section{REFERENCES}

Aanyu, M., Betancor, M.B., and Monroig, O. 2018. Effects of dietary limonene and thymol on growth and nutritional physiology of Nile tilapia (Oreochromis niloticus). Aquaculture. 488: 217-226. https://doi.org/ 10.1016/j.aquaculture.2018.01.036

Abdel-Tawwab, M., Adeshina, I., Jenyo-Oni, A., Ajani, E.K., and Emikpe, B.O. 2018. Growth, physiological, antioxidants, and immune response of African catfish, Clarias gariepinus (B.), to dietary clove basil, Ocimum gratissimum, leaf extract and its susceptibility to Listeria monocytogenes infection, Fish \& Shellfish Immunology. 78: 346-354. https://doi.org/ 10.1016/j.fsi.2018.04.057

Adham, K.G., Ibrahim, H.M., Hamed, S.S., and Saleh, R.A. 2002. Blood chemistry of the Nile tilapia, Oreochromis niloticus (Linnaeus, 1757). Aquatic Ecology. 36: 549-557. https://doi.org/10.1023/A:1021137122046 Ahmadifar, E., Sheikhzadeh, N., Roshanaei, K., Dargahi, N., and Faggio, C. 2019. Can dietary ginger (Zingiber officinale) alter biochemical and immunological parameters and gene expression related to growth, immunity and antioxidant system in zebrafish (Danio rerio)? Aquaculture. 507: 341-348. https://doi.org/10.1016/j.aquaculture. 2019.04.049 
Al-Dohail, M.A., Hashim, R., and Aliyu-Paiko, M. 2009. Effects of the probiotic, Lactobacillus acidophilus, on the growth performance, haematology parameters and immunoglobulin concentration in African Catfish (Clarias gariepinus, Burchell 1822) fingerling. Aquaculture Research. 40(14): 1642-1652. https://doi.org/10.1111/j.1365-2109.2009.02265.x

Awad, E., and Awaad, A. 2017. Role of medicinal plants on growth performance and immune status in fish. Fish \& Shellfish Immunology. 67: 40-54. https://doi.org/10.1016/j.fsi.2017.05.034

Bajgai, S.P., Prachyawarakorn, V., Mahidol, C., Ruchirawat, S., and Kittakoop, P. 2011. Hybrid flavan-chalcones, aromatase and lipoxygenase inhibitors, from Desmos cochinchinensis. Phytochemistry. 72: 2062-2067. https://doi. org/10.1016/j.phytochem.2011.07.002

Birchenough, G.M.H., Johansson, M.E.V., Gustafsson, J.K., Bergström, and Hansson, G.C. 2015. New developments in goblet cell mucus secretion and function. Mucosal Immunology. 8(4): 712-719. https://doi.org/10.1038/mi. 2015.32

Briggs, C., and Bain, B. J. 2017. Basic haematological techniques. In: Bain, B.J., Bates, I., Laffan, M.A., editors. Dacie and Lewis practical haematology. $12^{\text {th }}$ ed. Elsevier. p. 18-49. https://doi.org/10.1016/B978-0-7020-66962.00003-5

Cao, H., Yu, R., Zhang, Y., Hu, B., Jian, S., Wen, C., Kajbaf, K., Kumar, V., and Yang, G. 2019. Effects of dietary supplementation with $\beta$-glucan and Bacillus subtilis on growth, fillet quality, immune capacity, and antioxidant status of Pengze crucian carp (Carassius auratus var. Pengze). Aquaculture. 508: 106-112. https://doi.org/10.1016/j.aquaculture.2019.04. 064

Dong, H., Chen, S.-X., Xu, H.-X., Kadota, S., and Namba, T. 1998. A new antiplatelet diarylheptanoid from Alpinia blepharocalyx. Journal of Natural Products. 61(1): 142-144. https://doi.org/10.1021/np970293i

Fang, C., Ma, M., Ji, H., Ren, T., and Mims, S.D. 2015. Alterations of digestive enzyme activities, intestinal morphology and microbiota in juvenile paddlefish, Polyodon spathula, fed dietary probiotics. Fish Physiology and Biochemistry. 41(1): 91-105. https://doi.org/10.1007/s10695-014-0008-7

Fishery Statistics Analysis and Research Group. 2019. Fishery Statistics of Thailand 2017. No. 9/2019. Department of Fisheries. Ministry of Agriculture and Cooperatives.

Güllü, K., Acar, Ü., Kesbiç, O.S., Yılmaz, S., Ağdamar, S., Ergün, S., and Türker, A. 2015. Beneficial effects of oral allspice, Pimenta dioica powder supplementation on the hemato-immunological and serum biochemical responses of Oreochromis mossambicus. Aquaculture Research. 47(9): 2697-2704. https://doi.org/10.1111/are.12717 
Hatziieremia, S., Gray, A.I., Ferro, V.A., Paul, A., and Plevin, R. 2006. The effects of cardamonin on lipopolysaccharide-induced inflammatory protein production and MAP kinase and $\mathrm{NF}_{\mathrm{k}} \mathrm{B}$ signalling pathways in monocytes/macrophages. British Journal of Pharmacology. 149: 188-198. https://doi.org/10.1038/sj.bjp.0706856

Hoseini, S.M., Mirghaed, A.T., Iri, Y., and Ghelichpour, M. 2018. Effects of dietary cineole administration on growth performance, hematological and biochemical parameters of rainbow trout (Oncorhynchus mykiss). Aquaculture. 495: 766-772. https://doi.org/10.1016/j.aquaculture.2018. 06.073

Isa, N.M., Abdul, A.B., Abdelwahab, S.I., Abdullah, R., Sukari, M.A., Kamalidehghan, B., Hadi, A.H.A., and Mohan, S. 2013. Boesenbergin A, a chalcone from Boesenbergia rotunda induces apoptosis via mitochondrial disregulation and cytochrome c release in A549 cells in vitro: Involvement of HSP70 and Bcl2/Bax signaling pathways. Journal of Functional Foods. 5(1): 87-97. https://doi.org/10.1016/j.jff.2012.08.008

Kiat, T.S., Pippen, R., Yusof, R., Ibrahim, H., Khalid, N., and Rahman, N.A. 2006. Inhibitory activity of cyclohexenyl chalcone derivatives and flavonoids of fingerroot, Boesenbergia rotunda (L.), towards dengue-2 virus NS3 protease. Bioorganic \& Medicinal Chemistry Letters. 16(12): 3337-3340. https://doi.org/10.1016/j.bmcl.2005.12.075

Krishna, B.M., and Chaganty, R.B. 1973. Cardamonin and alpinetin from the seeds of Alpinia speciosa. Phytochemistry. 12(1): 238. https://doi.org/ 10.1016/S0031-9422(00)84672-5

Lazo, J.P., Darias, M.J., and Gisbert, E. 2011. Ontogeny of the digestive tract. In: Holt, G.L. editor. Larval fish nutrition. John Wiley \& Sons, Inc. U.K. pp.546. https://doi.org/10.1002/9780470959862.ch1

Li, M., Zhu, X., Tian, J., Liu, M., and Wang, G. 2019. Dietary flavonoids from Allium mongolicum Regel promotes growth, improves immune, antioxidant status, immune-related signaling molecules and disease resistance in juvenile northern snakehead fish (Channa argus). Aquaculture. 501: 473-481. https://doi.org/10.1016/j.aquaculture.2018.12. 011

Lim, K.C, Yusoff, F.Md., Shariff, M., Kamarudin, M.S., and Nagao, N. 2019. Dietary supplementation of astaxanthin enhances hemato-biochemistry and innate immunity of Asian seabass, Lates calcarifer (Bloch, 1790). Aquaculture. 512: 734339. https://doi.org/10.1016/j.aquaculture.2019.73 4339

Marshall, W., Bangert, S., and Lapsley, M. 2012. Clinical chemistry. $7^{\text {th }}$ ed. Elsevier Ltd. 
Memon, A.H., Ismail, Z., Aisha, A.F.A., Al-Suede, F.S.R., Hamil, M.S.R., Hashim, S., Saeed, M.A.A., Laghari, M., and Abdul Majid, A.M.S. 2014. Isolation, characterization, crystal structure elucidation, and anticancer study of dimethyl cardamonin, isolated from Syzygium campanulatum Korth. Evidence-Based Complementary and Alternative Medicine. 2014. https://doi.org/10.1155/2014/470179.

Munglue, P., Rattana, K., Sangchanjiradet, S., and Dasri, K. 2019a. Effect of dietary lasia (Lasia spinosa (L.) Thwaites) extract on growth performance and intestinal histology in hybrid catfish (Clarias macrocephalus $\times$ Clarias gariepinus). Chiang Mai University Journal of Natural Sciences. 18(2): 226-249. https://doi.org/10.12982/CMUJNS.2019.0017

Munglue, P., Rattana, K., Sangchanjiradet, S., Jankam, A., and Dasri, K. 2019b. Growth performance and intestinal morphology of hybrid catfish (Clarias macrocephalus $\times$ Clarias gariepinus) fed diet supplemented with rice paddy herb (Limnophila aromatica) extract. Asia-Pacific Journal of Science and Technology. 24(2): 1-12. https://doi.org/10.14456/apst.2019. 17

Mutlu, E., Aydın, S., and Kutlu, B. 2015. Alterations of growth performance and blood chemistry in Nile tilapia (Oreochromis nioticus) affected by copper sulfate in long-term exposure. Turkish Journal of Fisheries and Aquatic Sciences. 15: 487-493. https://doi.org/10.4194/1303-2712-v15_2_35

Pês, T.S., Saccol, E.M.H., Ourique, G.M., Londero, É.P., Gressler, L.T., Finamor, I.A., Rotili, D.A., Golombieski, J.I., Glanzner, W.G., Llesuy, S.F., et al. 2015. Effect of diets enriched with rutin on blood parameters, oxidative biomarkers and pituitary hormone expression in silver catfish (Rhamdia quelen). Fish Physiology and Biochemistry. 42(1): 321-333. https://doi.org/10.1007/s10695-015-0140-z

Pês, T.S., Saccol, E.M.H., Ourique, G.M., Londero, É.P., Gressler, L.T., Golombieski, J.I., Glanzner, W.G., Llesuy, S.F., Gonçalves, P.B.D., Neto, J.R., et al. 2016. Quercetin in the diet of silver catfish: Effects on antioxidant status, blood parameters and pituitary hormone expression. Aquaculture. 485: 100-106. https://doi.org/10.1016/j.aquaculture.2016. 02.020

Picoli, F., Lopes, D.L.deA., Zampar, A., Serafini, S., Freccia, A., Veronezi, L.O., Kowalski, M.W., Ghizzo, J.B., and Emerenciano, M.G.C. 2019. Dietary bee pollen affects hepatic-intestinal histomorphometry of Nile tilapia fingerlings. Aquaculture Research. 50(11): 3295-3304. https://doi.org/ 10.1111/are.14287

Ping, C.P., Mohamad, T.A.S.T., Akhtar, M.N., Perimal, E.K., Akira, A., Israf Ali, D.A.I., and Sulaiman, M.R. 2018. Antinociceptive effects of cardamonin in mice: Possible involvement of TRPV1, glutamate, and opioid receptors. Molecules. 23(9): 2237. https://doi.org/10.3390/molecules23092237 
Ramezanzadeh, S., Kenari, A.A., and Esmaeili. 2019. Immunohematological parameters of rainbow trout (Oncorhynchus mykiss) fed supplemented diet with different forms of barberry root (Berberis vulgaris). Comparative Clinical Pathology. 1-11. https://doi.org/10.1007/s00580-019-03032-8

Reda, R.M., Ibrahim, R.E., Ahmed, E.G., and El-Bouhy, Z.M. 2013. Effect of oxytetracycline and florfenicol as growth promoters on the health status of cultured Oreochromis niloticus. Egyptian Journal of Aquatic Research. 39: 241-248. https://doi.org/10.1016/j.ejar.2013.12.001

Reverter, M., Bontemps, N., Lecchini, D., Banaigs, B., and Sasal, P. 2014. Use of plant extracts in fish aquaculture as an alternative to chemotherapy: current status and future perspectives. Aquaculture. 433: 50-61. https://doi.org/10.1016/j.aquaculture.2014.05.048

Rodriguez Montes de Oca, G.A. 2005. Evaluation of dietary phytochemicals on sex differentiation and growth in Nile tilapia (Oreochromis niloticus) [dissertation]. OH: The Ohio State University.

Sarvi Moghanlou, K., Isfahani, E.N., Dorafshan, S., Tukmechi, A., and Aramli, M.S. 2018. Effects of dietary supplementation with Stachys lavandulifolia Vahl extract on growth performance, hemato-biochemical and innate immunity parameters of rainbow trout (Oncorhynchus mykiss). Animal Feed Science and Technology. 237: 98-105. http://doi.org/10.1016/ j.anifeedsci.2018.01.016

Sruthi, M.V., Nair, A.B., Arun, D., Thushara, V.V., Sheera, C.C., Vijayasree, A.S., Oommen, O.V., and Divya, L. 2018. Dietary curcumin influences leptin, growth hormone and hepatic growth factors in tilapia (Oreochromis mossambicus). Aquaculture. 496: 105-111. https://doi.org/10.1016/j. aquaculture.2018.06.083

Sun, Z., Tan, X., Ye, H., Zou, C., Ye, C., and Wang, A. 2018. Effects of dietary Panax notoginseng extract on growth performance, fish composition, immune responses, intestinal histology and immune related genes expression of hybrid grouper (Epinephelus lanceolatus $\hat{\sigma} \times$ Epinephelus fuscoguttatus ( ) fed high lipid diets. Fish \& Shellfish Immunology. 73: 234-244. https://doi.org/10.1016/j.fsi.2017.11.007

Tan, X., Sun, Z., Zhou, C., Huang, Z., Tan, L., Xun, P., Huang, Q., Lin, H., Ye, C., and Wang, A. 2018. Effects of dietary dandelion extract on intestinal morphology, antioxidant status, immune function and physical barrier function of juvenile golden pompano Trachinotus ovatus. Fish and Shellfish Immunology. 73: 197-206. https://doi.org/10.1016/j.fsi.2017. 12.020

Tewtrakul, S., Subhadhirasakul, S., Puripattanavong, J., and Panphadung, T. 2003. HIV-1 protease inhibitory substances from the rhizomes of Boesenbergia pandurata Holtt. Songklanakarin Journal of Science and Technology. 25: 503-508. 
Tiengtam, N., Khempaka, S., Paengkoum, P., and Boonanuntanasarn, S. 2015. Effects of inulin and Jerusalem artichoke (Helianthus tuberosus) as prebiotic ingredients in the diet of juvenile Nile tilapia (Oreochromis niloticus). Animal Feed Science and Technology. 207: 120-129. https://doi.org/10.1016/j.anifeedsci.2015.05.008

Tram, L.H., Giang, P.G., and Son, P.T. 2007. Biologically active phenolic constituents from Alpinia gagnepainii K. Schum (Zingiberaceae). Journal of Chemistry. 45(1): 126-130.

Van Doan, H., Hoseinifar, S.H., Chitmanat, C., Jaturasitha, S., Paolucci, M., Ashouri, G., Dawood, M.A.O., and Esteban, M.Á. 2019. The effects of Thai ginseng, Boesenbergia rotunda powder on mucosal and serum immunity, disease resistance, and growth performance of Nile tilapia (Oreochromis niloticus) fingerlings. Aquaculture. 513: 734388. https://doi. org/10.1016/j.aquaculture.2019.734388

Van Hai, N. 2015. The use of medicinal plants as immunostimulants in aquaculture: a review. Aquaculture. 446: 88-96. https://doi.org/10.1016/ j.aquaculture.2015.03.014

Villasante, A., Powell, M.S., Moutou, K., Murdoch, G.K., Overturf, K., Wacyk, J., and Hardy, R.W. 2016. Effects of anthocyanidins on myogenic differentiation and antioxidant defense in primary myogenic cells isolated from rainbow trout (Oncorhynchus mykiss). Aquaculture. 454: 81-89. https://doi.org/10.1016/j.aquaculture.2015.12.007

Wang, Z.-T., Lau, C.-W., Chan, F.L., Yao, X., Chen, Z.Y., He, Z.D., and Huang, Y. 2001. Vasorelaxant effects of cardamonin and alpinetin from Alpinia henryi K. Schum. Journal of Cardiovascular Pharmacology. 37(5): 596-606. https://doi.org/10.1097/00005344-200105000-00011

Wilson, J.M., and Castro, L.F.C. 2011. Morphological diversity of the gastrointestinal tract in fishes. In: Grosell, M., Farrell, A.P., and Brauner, C.J. editors. the Multifunctional Gut of Fish. London: Academic Press. p. $1-55$.

Yamamoto, N., Kawabata, K., Sawada, K., Ueda, M., Fukuda, I., Kawasaki, K., Murakami, A., and Ashida, H. 2011. Cardamonin stimulates glucose uptake through translocation of glucose transporter-4 in L6 myotubes. Phytotherapy Research. 25(8): 1218-1224. https://doi.org/10.1002/ptr. 3416

Zhang, J., Sikka, S., Siveen, K.S., Lee, J.H., Um, J.Y., Kumar, A.P., Chinnathambi, A., Alharbi. S.A., Basappa, Rangappa, K.S., et al. 2017. Cardamonin represses proliferation, invasion, and causes apoptosis through the modulation of signal transducer and activator of transcription 3 pathway in prostate cancer. Apoptosis. 22(1): 158-168. https://doi.org/ $10.1007 / \mathrm{s} 10495-016-1313-7$ 